\title{
The Study on Heilongjiang Poverty Alleviation Issues
}

\author{
Jiang Bowei, Zhao Yingjie \\ College of Humanities and Law of Northeast Forestry University, Harbin, Heilongjiang 150040, China \\ zyj82190411@163.com
}

\begin{abstract}
Poverty alleviation has been one of the important work related to people's livelihood. Through the analysis of achievements and problems of Heilongjiang poverty alleviation. This article puts forward the concrete ideas and measures to improve the work to achieve for Heilongiiang province government related part of its decision to provide the reference. At the same time it hopes to be able to achieve the effect of point to area in order to provide reference for other provinces to improve the effect of poverty alleviation work.

Index Terms - Poverty Alleviation, Industrial Poverty Alleviation, Regulatory Capital

\section{The Achievements of Poverty Alleviation Work in Heilongjiang Province}

Entering the new century. According to the national deployment, Heilongjiang province has established "the heilongjiang province rural poverty alleviation and development program (2001-2010)", explicitly proposed "as soon as possible to solve the poor food and clothing, eliminating absolute poverty" goals, and confirmed "One plan, two years of implementation, village-by-village acceptance, partial advance" of the whole village to promote poverty alleviation and development strategy[1]. Ten years after the province's poor areas cadres and masses, the joint efforts of poverty alleviation and development has made some progress.

In 2013, the province has invested financial poverty alleviation fund 808.58 million yuan[2]. Through the implementation of continuous destitute areas in crucial for poverty alleviation, the whole village to promote, industry for poverty alleviation, poor labor training, construction of old revolutionary base areas and so on. The province has a total of 120000 rural poverty population got rid of poverty[3]. The implementation of whole village advancement, the per capita net income of farmers reached 4,095 yuan in impoverished village[4]. Therefore, the successful completion of the tasks throughout the year.

\section{A. To Organize the Formulation of the Province Area \\ Planning and Industry Planning for Poverty Alleviation}

According to the State Council approved the greater hinggan mountains in our province of south mountain shall destitute areas planning. On the basis of 11 district planning at the county level, our province has completed the poor area implementation planning and industrial planning for poverty alleviation and reported to the state for the record.

\section{B. The Implementation of Poverty Alleviation and \\ Development of Whole Village Advancement}

The "Twelfth Five Year Plan" the first batch of (20122013) the poor villages last year to promote the work of.
Issued the whole village advancement fund project 30,370 million Yuan. Integration of industry sector funds more than 1billion Yuan, the village is more than 2,000,000 Yuan of investment. Implementation of industrial income, infrastructure, living environment and ecological construction, social construction projects directly support 51,000 poor households, benefiting 273,000 household.Promote industrial restructuring poor villages, improving production and living conditions of poor people, poor villages whole village per capita income of 4,095 Yuan, an increase of $21 \%$ compared to 2012. Successful completion of the "five" the first task of the whole village, to achieve the target of 12 million people out of poverty.

\section{Carry Out Industrial Poverty}

In the whole village as a platform to establish cooperative economic organizations of farmers, promoting new breakthroughs on land transfer and industrial development in poor villages. To provide a guarantee for the realization of increasing the income of poor farmers. Built 30 farming cooperatives, bought 160 (sets) of large agricultural machinery, supported the poor households to the introduction of new varieties of 193.3 tons of grain crops, planted grapes, strawberries and other specialty crops 13,452 acres, built 337,000 square meters of plastic greenhouses, energy greenhouse 22,200 square meters and constructed 2 animal husbandry and technical service stations, raising house of 38,544 square meters .

\section{Deepening Poverty Labor Force Training}

This year, the province invested "rain plan" pro-poor training funds $8,891,100$ Yuan, of which, carry out 2,000 training classes in 500 poor villages, training 17,900 farmers, covering 57,000 workforce; poor families attending vocational education funding grants 3615 people. Use national "rain plan" pilot funds $1,630,500$ Yuan to subsidize students of 1,087 people.

\section{E. Development of Old Revolutionary Base Areas and Construction Work}

The old revolutionary base construction funds invested 10 million Yuan. The old revolutionary base construction funds for 68 old revolutionary base village, building much-needed mass production and life projects. Completed projects Yanshou central lottery pilot 10 villages. Two years, a total investment of 6997.7 million Yuan, of which the central lottery public welfare fund 1,500 million Yuan. Organize the Raohe County Central lottery pilot project construction. Using the special lottery public welfare fund 15,000,000 Yuan to 
support the Raohe County Xiao Jia He town and Da Jia He township of merging 10 villages to carry out poverty in old revolutionary base areas of whole village advancement and pilot project. Currently completed the five villages construction projects.

\section{F. Steadily Promote Poverty Alleviation and Development of the Pilot}

First, earnestly carry out poverty alleviation loan discount pilot. National Poverty discount loans issued by the province this year, 12 million yuan of funds, poor households interest payments on loans and interest payments on loans for each project 6 million. Loans 120 million Yuan, 24,000 beneficiary; poverty enterprises, industrial base, farmer cooperatives and large breeding loan of 2.5 billion, 8,000 to benefit poor households, poverty alleviation loan interest subsidy benefits are obvious. Second, the depth of poverty villages mutual funds pilot. 247 pilot villages of the province, the stock of capital 112 million Yuan, of which financial funds 72.2 million Yuan, 39.81 million Yuan of funds join a company of poor households, poor households borrowing 62,570,000 Yuan. The third is to actively promote the forest, mining and urban poverty alleviation and development pilot. Invested 30 million yuan of funds, for the forest, mining poor workers, income poverty has a role in boosting industrial projects, into the city," a bunch of a "poverty alleviation funds 75,160,000 Yuan, helping 136,000 poor urban workers.

\section{The Problem Existing in the Heilongjiang Poverty Alleviation Work}

\section{A. Difficulty of Consolidating the Achievement of Poverty}

Returning to poverty issues outstanding, consolidate the achievements of poverty is difficult. According to statistics, 2012 the province's film counties, per capita net income of farmers in key counties have 4,493 Yuan, poverty object has $1,196,305$ people, in 2013 the per capita net income of farmers have 4,034 Yuan, the number of poverty alleviation object has $1,215,607$ people. Revenue decreased by $10.22 \%$ compared to last year, an increase of $1.61 \%$ over the poverty target last year. Affected by the serious natural disasters, 20\% part per capita net income of farmers appeared a negative growth.

\section{B. Matching Funds Shortage}

Countries ask for $70 \%$ special aid-the-poor funds of the central finance to household and industrial projects, infrastructure and public welfare projects in poor villages lack of funds. According to the national poverty alleviation of poverty alleviation and development evaluation and performance appraisal work requirements, the provincial finance has a certain proportion of matching funds, our province finance special funds supporting investment insufficience.

\section{Poor Farmers' Income Space Narrowing}

Affected by the global and domestic economic slowdown, leading to oversupply of agricultural products, livestock prices decline. In addition, a weak labor market, resulting in the employment of migrant workers. These factors directly affect the steady growth of farmers' income poverty.

\section{Specific Measurements to Improve the Poverty Alleviation Work in Heilongjiang}

General requirements of the province's poverty alleviation and development work are: Conscientiously implement the spirit of eighteen and eighteen in the second, the Third Plenary Session of the party, a series of important instructions on poverty alleviation and development work should be based on the guidance of Xi Jinping and other central leaders, combined with practical work of poverty alleviation and development in our province, under the leadership of the provincial party committee, the provincial government, adhere to the road of great poverty, the main responsibility for the implementation of enhanced efforts to crack the problem of poverty, accelerate the pace of poverty in poor areas .

The main objective of the mission is: the main battlefield in south of Greater Khingan Range poor area, the national and provincial poverty county andthe second batch of the impoverished village. Through the whole village, industrial development, poor households workforce training, infrastructure and social services, construction, realized the 100,000 rural poor out of poverty, the implementation of the whole village poor villages of farmers per capita net income reached 4,000 yuan or more. Continue to do the forest, mining and development of old revolutionary base areas poverty, backwardness in poor areas to get rid of as soon as possible.

\section{A. Fully Grasp the Construction of Poverty and Strive to Make Breakthroughs in the Outcome of Poverty}

1) The completion of the second installment of the poor villages in the first year of the task. Acceptance summarized the whole village, "Twelfth Five Year Plan" first batch (2012 2013) poor villages to promote the work, to start the implementation of the second batch of the whole village (2014 -2015) poor villages advance planning. In accordance with the requirements of the development of modern agriculture, combined with the construction of the "Two Great Plains" modern agriculture comprehensive reform pilot area, Increase support for Infrastructure, increase industry, social services and the construction of residential environment, strengthen leading enterprises and professional cooperative organizations such as the production and business operation main body to drive the poor to increase income.

2) The implementation of the poverty-stricken Area tackling poverty alleviation and development projects. Daxing'anling Area and the south of the country destitute and poverty-stricken counties Province, focusing on the implementation of Area Planning and creative industries poverty reduction program. Strengthening of infrastructure and social services, based on the scale to develop farming and livestock breeding industry, highlighting the development of agro-industries and special industries. Coordinate and implement policies on the national and provincial support for destitute and poverty-stricken counties Area, leveraging 
financial and social capital with financial funds to increase investment in poor areas .

\section{B. Innovation Poverty Alleviation and Development Work Mechanism, Strive for New Achievements in Poverty Reduction in the Community}

1) Increased Training Efforts. In accordance with the modernization of agriculture to new farmers ( knowledge, understand technology, management) requirements, the full implementation of "rain plan" real-name system for training and subsidies for poverty reduction target needs training in practical skills training, training, and student leaders of the rich subsidies work and strive for new breakthroughs.

2) Strengthen Poverty Alleviation. Mobilize and organize the party and government organs, enterprises, universities, research institutes, military and police forces and community support to help poor areas. Helping to implement the responsibility, sum, marketing experience, enhance the level of poverty alleviation work.

3) Further Promote Poverty Alleviation and Development of the Pilot. First, deepen mutual funding fund pilot work. Specification poor villages mutual funds organizational development, control liquidity risk. Second, make poverty alleviation loan discount pilot. Financial funds play a leveraging effect, amplifying the effect of poverty relief funds. Leading enterprises to increase poor households and poverty alleviation loan interest support. Third is to promote a special lottery to support the central revolutionary base areas and the whole village pilot forest, mining, urban poverty alleviation pilot.

4) Establishment of cadres system. Residency Task Force sent in batches to the poor villages, send cadres to poor villages attachment or office, to poverty alleviation and development as a training exercise cadres institutional platform. Assist grassroots organizations implement the party's policy to help tackle poverty villages lack of talent, lack of technology, lack of funds, lack of information and other outstanding issues.

C. Strengthen the Supervision of Project Funding for Poverty Alleviation, and Strive to Make New Achievements in the

Performance Appraisal

Strengthen management and supervision, improve the assessment mechanism. The poverty alleviation fund allocation and performance assessment linked to substitute subsidies with rewards and other competitive allocation. Strengthen the capital project supervision, all-the-way tracking and project construction by use of funds, strengthening the implementation of regulatory responsibility, the implementation of strict accountability and reward. Play a role in social supervision. Auditing, discipline inspection and supervision departments to strictly investigate and discipline violations. Revised " Regulations of Heilongjiang Province Rural Poverty Alleviation and Development" to promote the legalizationprocess poverty.

\section{References}

[1] Thomson and Marie,A. (2006). Collaboration Process: Inside the Black Box. Public Administration Review, Vol. 66, No.s1:.20-32.

[2] O'Toole and Laurence,J.J. (1988). Strategic for Intergovernmental Management: Implementing Pr ograms in Interorganizational Networks. International Journal of Public Administration 11(4): 417-441.

[3] Morgenthau,H.(1962). A Political Theory of Foreign Aid .The American Political Science Review, Vol.56 (No.2): pp.301-309.

[4] Vengroff, R. (1982). Food and Dependency: Aid to Black Af-rica. Journal of Mordern African Studies, 20 (1): 43. 